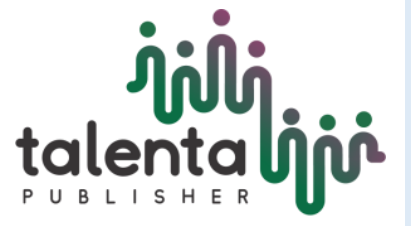

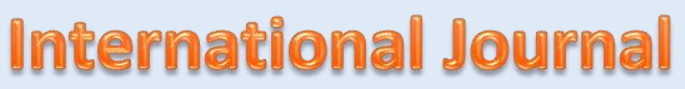
of Ecophysiology

\title{
Wealth Study of Types Of Rats On Natural And Made In Ecosystems In Bengkulu Province
}

\author{
Rizwar $^{1}$, Santi N. Kamilah ${ }^{1}$, Darmi $^{1}$, Rhama Wijaya ${ }^{1}$, Dwi K. Ningrum ${ }^{1}$, \\ Arisa Anugrah ${ }^{1}$ \\ ${ }^{1,}$ Department of Biology FMIPA Universitas Bengkulu, Jalan WR Supratman Kandang Limun Kota \\ Bengkulu
}

\begin{abstract}
Rats are cosmopolitan animals because they are able to adapt to environmental changes. These small mammals can be found from primary and secondary forests, plantation areas, rice fields to human settlements. The species richness, distribution, size and dynamics of rats in an ecosystem are determined by external factors such as climate, season, availability of food, habitat / ecosystem type, barrier, type of vegetation cover, soil type, competition, predation and internal factors such as age structure and fertility. This study aims to analyze the richness of rats in natural ecosystems such as secondary forests, swamp forests, grasslands and artificial ecosystems such as palm plantation ecosystems, rubber plantations and rice field ecosystems in Bengkulu Province. The study is located around Bengkulu University, Rojolelo Park, palm plantation of PT. Bio Nusantara, North Bengkulu regency and Mekar Jaya village in Muko-Muko Regency. The study was conducted for four (4) months from April to August 2016. Rats were collected using clamps traps and all traps placed in the study areas used purposive sampling method. The results of the study found five (5) species of rats occupying different ecosystems, namely Rattus tiomanicus, $R$. exulans, $R$. argentiventer, $R$. novergicus and Mus musculus castaneus. Species of $R$. tiomanicus and $R$. exulans are cosmopolitan species that occupy all types of ecosystems. $R$. argentiventer are characteristic in rice field ecosystem, $R$. novergicus occupies only palm and rubber plant ecosystems while Mus musculus castaneus is found only in palm and paddy field ecosystem
\end{abstract}

Keywords: Species Richness, Rats, Natural and Artificial Ecosystem

Received 12 May 2018 | Revised 20 May 2018 | Accepted 22 June 2018

\section{Introduction}

The conversion of natural forest ecosystems to artificial ecosystems such as plantations and rice fields is one of the factors causing the loss of the main habitat of mammals in the Bengkulu province. Forest conversion also has an impact on decreasing biodiversity, the formation of small populations that are vulnerable to extinction due to genetic drift and disease or increasing animal populations that are pest (Primack, 1981).

\footnotetext{
*Corresponding author at: Jalan WR Supratman Kandang Limun Kota Bengkulu. Indonesia

E-mail address: rizwar.sikumbang@gmail.com
}

Copyright (C) 2018 Published by Talenta Publisher, e-ISSN: 2656-0674

Journal Homepage: http://ijoep.usu.ac.id 
Mammalian that live in natural ecosystems conversion usually already adapted to environmental changes and one of them is rats (Ario, 2010). Rats are a group of small mammals in the rodentia order that have 2700 species throughout the world. Two-thirds of the Rodentia is Muridae family (Payne et al., 2000; Aplin et al., 2003). The existence of rats in an ecosystem can have positive and negative impacts on the environment. The positive impact, mice play an important role in the health of natural and artificial ecosystems because rodentia are the main food for predatory animals such as snakes, eagles, owls, cats, etc. The other roles rats as spreaders of seeds or plant seeds, pollinating agents(Suyanto, 2005 ), while the negative impact is that rats can become infectious pests to human and as diseases vectors such as leptospirosis, plaque, and thyphosa (Ristiyanto, 1994).

The ability to adapt to environmental changes lead to rats can be found in various ecosystems. Rats can be found in primary, secondary, plantation and rice fields in human settlements (Payne et al., 2000). In addition, rats also fast-breeding animals, they are relatively fast to reproduce so that their population increase in short period of time (Sofyan et al., 2008). Handika (2013) reported that five types of mice found in Singgalang mountain (WestS umatera) such as Leopoldamys sabanus, Sundamys infraluteus, Maxomys hylomyoides, M. Surifer and Niventer rapid. Whereas, Fajri (2005)stated that L. Sabanus, M. Surifer, M. rajab, M. Whiteadi and S. Muelleri were found in Palung mountain National Park forest in West Kalimantan. Study by Maryanto et al. (2000) in the industrial Albizia plantations ecosystem found Maxomys whiteadi, M. Rajah, Rattus tanezumi, R. exulans and R. tiomanicus. Ernawati \& Dwi (2013) found $R$. tanezumi and $R$. norvegicus in the market town of Banjarnegara.

Rat species that occupy an ecosystem are determined by many ecological factors such as external factors such as climate, season, food, habitat type, barrier, type of vegetation cover, soil and others as well as internal factors such as ability to compete and avoid predation, age structure, fertility and others (Krebs, 1978; Odum, 1971).

Bengkulu has a variety of ecosystems ranging from natural ecosystems such as primary and secondary forests, swamp forests, grasslands to artificial ecosystems such as oil palm plantation, rubber and rice fields. Mice with varied types occupy a variety of habitat types, but so far there has been no scientific information about what types of mice live in these ecosystems. This study aims to analyze the wealth of rats species in natural ecosystems such as secondary forests, swamp forests, grasslands and artificial ecosystems, namely the ecosystem of oil palm plantations, rubber plantations and rice field ecosystems.

\section{Materials and Methods}

The study took place in several ecosystems including secondary forests, swamp forests and grasslands in the UNIB and Tahura Rojolelo neighborhoods, the oil palm plantation ecosystem in the area of PT. Bio Nusantara North Bengkulu, the area around UNIB, the area in Mekar Jaya 
village in Muko-Muko and Tahura Rojolelo, the rubber plantation ecosystem in the Mekar Jaya village area, Muko-Muko, rice field ecosystem in the area around UNIB and Tahura Rojolelo. The study lasted for four (4) months from April to August 2016.

Direct surveys of natural and artificial ecosystems as described above are carried out to determine representative land and can be used as a study area specifically for the installation of rat traps. Ten (10) fruit traps that have been prepared with bait in the form of roasted coconut are placed at points in the designated location. The method of spreading rod clamp traps at the study site used purposive sampling method, which was based on the signs of the presence of rats in the area such as holes in the soil, traces, paths, remnants of dirt and food debris, fallen trees and weathered, water channels and residential areas (Bismark, 2011; Payne et al., 2000; Cunningham $\&$ Moors, 1996). Installation and laying of traps at the research location were carried out in the afternoon starting at $16.00 \mathrm{WIB}$ and re-examined the next morning at $07.00 \mathrm{WIB}$. The location of each trap is marked with a wooden stick with a red ribbon. Trapping is carried out in five (5) replications where all the traps are installed on the checking day, especially in the afternoon.

Rat samples collected for four months in the field were identified in the Ecology-Conservation laboratory at the University of Bengkulu FMIPA. Identification of types using an identification guide from Cunningham \& Moors (1996), Aplin et al. (2003), Payne et al. (2000) and Yasuma et al. (2003). The types of mice that were identified were arranged in the inventory list and equipped with photographs. Each type is described using the reference book or guide.

\section{Result and Discussion}

\section{a. Types and Distribution of Mice Collected from Several Types Ecosystem}

During the four months of the study in several ecosystem types, 72 individual mice were collected, consisting of five types, namely Rattus tiomanicus, $R$. exulans, $R$. argentiventer, $R$. novergicus and Mus musculus castaneus (Table 1).

Table 1. Types of mice that are collected and distributed in several types of ecosystems

\begin{tabular}{|c|c|c|c|c|c|c|c|}
\hline \multirow{2}{*}{ No } & \multirow{2}{*}{ Rat Type } & \multicolumn{6}{|c|}{ Types of Ecosystems } \\
\hline & & SF & SWF & GL & OPP & FR & RF \\
\hline 1 & $\begin{array}{l}\text { Rattus } \\
\text { tiomanicus }\end{array}$ & $\sqrt{ }$ & $\sqrt{ }$ & $\sqrt{ }$ & $\sqrt{ }$ & $\sqrt{ }$ & $\sqrt{ }$ \\
\hline 2 & Rattus exulans & $\sqrt{ }$ & $\sqrt{ }$ & $\sqrt{ }$ & $\sqrt{ }$ & - & $\sqrt{ }$ \\
\hline
\end{tabular}




\begin{tabular}{llllllll}
\hline \multirow{2}{*}{ No } & Rat Type & \multicolumn{7}{c}{ Types of Ecosystems } \\
\cline { 3 - 8 } & & SF & SWF & GL & OPP & FR & RF \\
\hline 3 & $\begin{array}{l}\text { Rattus } \\
\text { argentiventer }\end{array}$ & - & - & - & - & - & $\sqrt{ }$ \\
& & & & & & & \\
\hline 4 & $\begin{array}{l}\text { Rattus } \\
\text { novergicus }\end{array}$ & - & - & - & $\sqrt{ }$ & \\
& & & & & & & \\
\hline 5 & $\begin{array}{l}\text { Mus musculus } \\
\text { castaneus }\end{array}$ & - & - & - & $\sqrt{ }$ & \\
& & & & & & \\
\hline
\end{tabular}

Remarks: SF $=$ Secondary forest, $\mathrm{SWF}=$ Swamp forest, $\mathrm{GL}=$ Grassland, OPP $=$ Oil palm plantation, FR $=$ Farm rubber, $\mathrm{RF}=$ Rice field,$\sqrt{ }=$ Yes, $(-)=$ none

Rattus is the most abundant genus of four species. Of the five trapped mice, Rattus tiomanicus and R. exulans were cosmopolitan species found in all types of ecosystems. In contrast $R$. argentiventer is only found in rice field ecosystems. Similar conditions were found in Rattus novergicus which was only found in the palm and rubber plantation ecosystems and the castaneus Mus musculus which was only found in the oil palm and rice field ecosystems.

Genus Rattus is a group of mice that have a very wide distribution because of its ability to easily adapt to environmental changes and be able to occupy different ecosystems by consuming a variety of food sources (Suyanto, 2002). Ratus tiomanicus and R. exulans are found in all types of ecosystems because this type is not only easy to adapt to new environments with varied feed preferences but also has the ability to breed quickly (Sudarmaji, 2005).

Rattus argentiventer is only found in rice field ecosystems and does not spread to other ecosystems because the main habitat of this type is the rice field area by making nest burrows in rice fields. These mice live not far from water channels that are overgrown with shrubs or weeds. Rice plants are the main food and are very popular with these rats so that the population is commonly found in rice field ecosystems (Singleton et al., 2010, Priyambodo, 1995; Rahmini, 1997).

Rattus novergicus and Mus musculus castaneus are types of mice found only in oil palm or rubber plantations and rice fields. These types are often found to live on piles of palm fronds and leaf litter, twigs and stems of rubber plants, especially those adjacent to water channels. M. musculus castaneus is also often found in human settlements adjacent to plantations (Yasuma et 
al., 2003). Castaneus mus musculus has climbing skills and often lives close to water bodies such as river banks and irrigation canals (Aplin et al., 2003).

b. Description of the types of mice collected in several types of ecosystems

1. Rattus tiomanicus Miller. 1900

Classification according to Wilson \& Reeder (2005), this animal belongs to the Muridae Family with the genus Rattus. This species has a characteristic dorsal gray-brown hair, black body hair with white ventral hair and a dark brown tail. The average morphometric size of adult mice, length from nose tip to tail tip $29.2 \mathrm{~cm}$, tail length $14.3 \mathrm{~cm}$, hind leg length from heel to the longest toe toe $3.0 \mathrm{~cm}$ and ear length $2.1 \mathrm{~cm}$. Rattus tiomanicus is a thicket rat and spreads easily in various habitats, has a total length ranging from $14-18.8 \mathrm{~cm}$, tail length $12-18.1 \mathrm{~cm}$, hind legs 2.8 $3.5 \mathrm{~cm}$ and ear length 1.1-1 $2.8 \mathrm{~cm}$ (Cunningham \& Moors, 1996; Aplin et al., 2003; Payne et al., 2000 and Yasuma et al., 2003).

\section{Rattus exulans Peale 1848.}

Dorsal R. exulans rough and spiny grayish hair with black bodyguard hair, white to gray body ventral hair with a dark brown tail. The average body length is $12.1 \mathrm{~cm}$, the average length of the tail is $13.4 \mathrm{~cm}$, the length of the back leg is $2.5 \mathrm{~cm}$ and the ear length is $2.0 \mathrm{~cm}$. This type is a field mouse with a morphometric range of the body with a length of 10.1-13.8 cm, tail length 11.8-15.9 and hind legs 2.2-2.8 cm with ear sizes 1.1-2.8 cm (Cunningham \& Moors, 1996; Aplin et al., 2003; Payne et al., 2000) and Yasuma et al., 2003).

\section{Rattus argentiventer Miller 1900.}

Dorsal $R$. argentiventer hair is pale brown with fine black spots. Ventral hair is silvery gray with a dark smudge in the middle. Dark brown tail. Morphometrically, total body length included tail $31.5 \mathrm{~cm}$, body length $16.1 \mathrm{~cm}$, tail length $15.4 \mathrm{~cm}$ and length of hind legs $3.3 \mathrm{~cm}$ and ear length $2.3 \mathrm{~cm}$. Based on body range, head and body length 14-21 cm, tail length 13-19.2 cm, hind legs $3.2-3.5 \mathrm{~cm}$ and ears $1.8-3.0 \mathrm{~cm}$. The color of the hair on the feet is the same as the dorsal color of the body (Payne et., 2000; Aplin et al., 20003).

\section{Rattus novergicus Berkenhout, 1769.}

These mice have dorsal brown to gray hair with a slight black color and white ventral hair color to brass like milk color. The tail is black with scales covering the tail's surface. The average total body length includes tail $35.5 \mathrm{~cm}$, body length $18.0 \mathrm{~cm}$, length of back leg $3.5 \mathrm{~cm}$, tail length $17.5 \mathrm{~cm}$ and ears $2 \mathrm{~cm}$. The range of body length is $16-19,5 \mathrm{~cm}$, tail length $12-18,1 \mathrm{~cm}$, hind legs 2,8-3,5 $\mathrm{cm}$ and ears 1,1-2,5 $\mathrm{cm}$ (Payne et al., 2000). 
5. Mus musculus castaneus L, 1758.

Adult animals of this type are small, dorsal hair is brown to gray at the base of the hair. The ventral hair of the body is slightly pale. The hair is very soft, the whole tail is dark brown. Average total body length including tail $25 \mathrm{~cm}$, length from head to body $14 \mathrm{~cm}$, hind legs $3 \mathrm{~cm}$, tail length $15 \mathrm{~cm}$ and ears $2.8 \mathrm{~cm}$. Castaneus means "chesnut brown" or chestnut chocolate, these mice are found in many residential areas or human habitation (Yasuma et al., 2003).

\section{Conclussion}

From the results of a study on the richness of rat species in natural and artificial ecosystems in the province of Bengkulu, it can be concluded:

a. Recorded five (5) five types of rats that occupy different ecosystems, namely Rattus tiomanicus, $R$. exulans, $R$. argentiventer, $R$. novergicus and Musaneus castaneus.

b. Rattus tiomanicus and R. exulans are the species that have the most extensive distribution that occupies the types of natural ecosystems (secondary forests, swamp forests, grasslands) and artificial ecosystems (oil palm plantations, rubber gardens and rice fields).

c. $R$. argentiventer is a species that is characteristic of occupying the rice ecosystem, while $\mathrm{R}$. novergicus is only found in the oil palm and rubber plantations ecosystem and Mus musculus castaneus is found in the ecosystem of oil palm plantations and rice fields.

\section{References}

[1] Aplin, K.P., P.R. Brown, C.J. Krebs and G.R. Singleton, 2003. Field Method for Rodent Studies in Asia and the Indo-Pasific, Australian Centre for International Agricultural Research, Australia

[2] Ario, A. 2010. Mengenal Satwa Taman Nasional Gunung Gede Pangrango, Conservation International (CI)-Indonesia, Jakarta

[3] Bismark, M. 2011. Prosedur Operasi Standar (SOP) untuk Survei Keragaman Jenis pada Kawasan Konservasi, Kementerian Kehutanan RI, Bogor.

[4] Cunningham, D.M. and P.J. Moors, 1996. Guide to the Identification and Collection of New Zealand Rodents. Department of Conservation-Wellington, New Zealand

[5] Ernawati, D. Dan P. Dwi, 2013. Tikus Riul (Rattus novergicus Berkenhout, 1769.) Balaba 6 (2): 22-23.

[6] Fajri, M. 2005. Eksplorasi Tikus Hutan pada Ekosistem Dipterocarpaceae di Lubuk Baji Taman Nasional Gunung Palung Kalimantan Barat. BPPDKalimantan Timur. 
[7] Handika, H. 2013. Komunitas Mamalia Kecil Terestrial di Gunung Singgalang. Jurusan Biologi FMIPA, Universitas Andalas, Padang

[8] Krebs, C.J. 1978. Ecology the Experimental Analysis of Distribution and Abundance. Second Edition. Harper \& Row Publisher, New York, Hargestown, San Fransisco, London.

[9] Maryanto, L., A.P. Kartono dan M.H. Sinaga, 2000. Tikus pada Habitat yang Berbeda. Berita Biologi 5 (1): 119-123.

[10] Odum, E.P. 1971. Fundamentals of Ecology. Third Edition, Saunders College Publishing, Athens, Georgia.

[11] Payne, J., M.F. Charles, K. Phillips dan S.N. Kartikasari, 2000. Panduan Lapangan Mamalia di Kalimantan, Sabah, Sarawak dan Brunei Darussalam. Sabah Society, Malaysia.

[12] Primack, R.B. 1993. Essentials of Conservation Biology. Sinauer Associates, Inc. Sunderland, Massachussetts 01375 U.S.A.

[13] Priyambodo, S. 1995. Pengendalian Hama Tikus Terpadu. Penebar Swadaya, Jakarta.

[14] Rahmini, S. 1997. Penelitian Variasi Pakan Tikus Sawah pada Berbagai Stadia Pertumbuhan Tanaman Padi. Prosiding IIII Seminar Nasional Biologi XV. PPB Cabang Lampung dan UNILA, pp.1525-1528.

[15] Ristiyanto, 2007. Modul Pelatihan Rodensia. B2P2VRP, Salatiga.

[16] Singleton, G.R., S.R. Belmain, P.R. Brown and B. Hardy, et al., 2010. Rodent Outbreaks: Ecology and Impacts. International Rice Research Institute. Philipine.

[17] Sofyan, H.R.A., S. Widodo, E. Supeno, E. Minarni, F. Riyanti, I.N. Ibrahim, Suparwo, Gunawan, Ristianto, M. Reni, V. Widarsih, R. Haryanto, 2008. Buku Pedoman Pengendalian Tikus. Departemen Kesehatan Republik Indonesia, Jakarta

[18] Sudarmaji, 2005. Pengendalian Hama Tikus Terpadu untuk Mendukung P2BN (Peningkatan Produksi Beras Nasional), Direktorat Perlindungan Tanaman. Dirjen Tanaman Pangan, Jakarta.

[19] Suyanto, A. 2002. Keanekaragaman Mamalia Kecil di Hutan Lindung Gunung Lumut, Kabupaten Pasir, Kalimantan Timur, Zoo Indonesia 17(1):1-6.

[20] Wilson, D.E. and D.M. Reeder, 2005. Mammals Species of the World. A Taxonomic and Geographic Reference (3rd ed) Jhon Hopkin University Press.

[21] Yasuma, S.M., L. Danau, F.T.Y. Apia, Yu and L. Kimsui, 2003. Identification Keys to the Mammals of Borneo. BBEC Programme, Sabah. 